\title{
ANALYSIS OF AURORA KINASES GENES EXPRESSION POINTS ON THEIR DISTINCT ROLES IN PROSTATE CANCER DEVELOPMENT
}

\author{
O. MANKOVSKA ${ }^{1 凶}$, G. GERASHCHENKO ${ }^{1}$, E. ROZENBERG ${ }^{1}$, E. STAKHOVSKY ${ }^{2}$, \\ O. KONONENKO ${ }^{2}, Y$ Y BONDARENKO ${ }^{3}$, V. KASHUBA ${ }^{1,4}$ \\ ${ }^{1}$ Institute of Molecular Biology and Genetics, National Academy of Sciences of Ukraine, Kyiv; \\ ${ }^{2}$ National Cancer Institute, Ministry of Health of Ukraine, Kyiv; \\ ${ }^{3}$ Institute of Urology National Academy of Medical Sciences of Ukraine, Kyiv; \\ ${ }^{4}$ Department of Microbiology, Tumor and Cell Biology (MTC), \\ Karolinska Institutet, Stockholm, Sweden; \\ 凶e-mail: mankovsska@gmail.com
}

Received: 28 May 2019; Accepted: 18 October 2019

Aurora kinases $A$ and B play a crucial role in the regulation of mitosis, while Aurora $C$ controls meiotic division. These proteins showed controversial behavior upon the development of epithelial tumors. Our aim was to examine if there are any differences in expression of Aurora kinases genes in malignant and non-malignant tumors and non-tumor tissues; to compare their expression with clinical characteristics of patients and expression of other prostate cancer-associated genes. Quantitative RT-PCR was used to determine Aurora A-C genes expression in 33 prostate adenocarcinomas (T), paired conventionally normal tissues $(N)$, and 17 adenomas (A). Relative expression values (RE) for genes studied were estimated using $2^{-\Delta C t}$ and $2^{-4 \Delta C t}$ method. The Kruskal-Wallis with correction on multiple comparisons, according to the Benjamini-Hochberg procedure with FDR =0.2, Dunn-Bonferroni post hoc test and Spearman rank correlation analysis were used for statistical analysis. As turned out, RE values for AURKA were found to be significantly lower in samples of T group in comparison with A group. Moreover, significant up-regulation of AURKC expression levels were detected for T 3-4 stage compared to T 1-2 stage. RE values of AURKC in T group were positively correlated with the tumor stage, while AURKB RE demonstrated a negative correlation with the tumor stage. We also found significant correlations between AURK genes expression levels and prostate cancer-associated genes in $T$ group. We suppose that all these data point to probable involvement of Aurora kinases' genes in prostate carcinogenesis.

Keywords: prostate cancer, Aurora kinases, EMT genes, TMPRSS2-ERG fusion transcript, PTEN expression.

$\mathrm{P}$ rostate cancer $(\mathrm{PCa})$ is one of the most common oncological diseases in men, the second after lung cancer. In the last decades, intensive research was attempted to investigate diagnostic and prognostic PCa markers, novel therapy targets, mechanisms of the development of castration-resistant PCa (CRPC), etc. This increased our knowledge and improved treatment approaches. Nevertheless, the reasons, lying under genetic and epigenetic events during prostate cancer initiation and progression remain not fully understood. Great heterogeneity of PCa sets many challenges in a way of prediction of prostate cancer evolution and choice of appropriate therapy [1].

Somatic point mutations are less common in PCa than in most other solid tumors. The more general event for PCa is DNA copy-number variations. While indolent and low Gleason tumors have relatively not many such alterations, more aggressive primary and metastatic tumors have extensive occurrence of copy-number variations, genome-wide [2]. A huge number of chromosome rearrangements,

(c) 2019 Mankovska O. et al. This is an open-access article distributed under the terms of the Creative Commons Attribution License, which permits unrestricted use, distribution, and reproduction in any medium, provided the original author and source are credited. 
leading to large insertions, duplications, translocations and formation of aberrant gene fusions are usual events during prostate cancer progression [3]. One of the possible drivers of genomic rearrangements is an aberrant expression of key mitotic regulators, among which are kinases of an Aurora family $[4,5]$. Kinases of the Aurora family are the highly conserved serine/threonine kinases, the major regulators of the cell cycle, particularly spindle formation and chromosome segregation. Both, loss of function and overexpression of their genes can lead to malignant transformation via deviations in mitotic division, which occur as direct or indirect consequences of inappropriate functioning of the Aurora kinases [6].

Aurora A is encoded by the AURKA gene, which is localized on chromosome 20q13.2. There are 14 transcript variants of AURKA, encoding proteins from 9 to $46 \mathrm{kDa}$. This kinase is involved in several events during cell division, namely, the centrosome separation, microtubule formation and stabilization at the mitotic spindle, ensuring the accurate chromosome segregation. Aurora A regulates progression from G2 to M phase through Bora-mediated activation of Plk1 [7]. It was found, that this kinase, when overexpressed can transform NIH 3T3 cells and Rat1 fibroblasts in vitro [8]. Overexpression and amplification of the Aurora A kinase gene were described for a set of human cancers, including breast, urogenital, hematolymphoid, and also CNS lesions [9]. In gastric cancer, this is associated with aneuploidy, cell survival and taxane drug resistance [10].

The $A U R K B$ gene is localized on chromosome 17p13.1, encoding the second Aurora kinase, Aurora $\mathrm{B}$, consisting of 344 amino acids. This protein is a member of chromosomal passenger complex, functions at the beginning of mitosis and concentrates in the proximity of centromeres and kinetochores, where chromosome attachment to microtubules of the mitotic spindle is happening. In anaphase, Aurora $B$ shifts to the spindle equator. Aurora B regulates the interaction of kinetochores and chromosomes,

\footnotetext{
Abbreviations: AR - Androgen receptor; cDNA - Complementary DNA; CRPC - castration resistant prostate cancer; GS - Glisson score; mRNA - Messenger ribonucleic acid; PCa - Prostate cancer; PCAG - prostate cancer-associated genes; qPCR - Quantitative real time polymerase chain reaction; $\mathbf{R E ~ - ~ R e l a t i v e ~ g e n e ~ e x p r e s - ~}$ sion; SAC - Spindle assembly checkpoint.
}

segregation of sister chromatids and cytokinesis [11]. Recently, it was shown that Aurora B is an upstream regulator of the end-on conversion process [12]. Elevated levels of Aurora B were reported in prostate cancer cell lines and prostate tissues from patients with PCa [13].

Aurora C is a less studied member of Aurora kinase family, although it was discovered in the late 90s [14]. The AURKC gene is mapped on chromosome 19q13.43, and 3 transcript variants exist, encoding proteins of 275-309 residues. This protein is rather specific for germ cells and works during meiotic cell division. It is associated with Aurora B and Survivin in vivo [15]. Its function is very similar to the Aurora B kinase, but, probably, it has different regulation (due to the absence of $\mathrm{N}$-terminal domain with regulatory motifs). Moreover, overlapping in functions is not absolute, and those two Aurora kinases are unique in this sense. For instance, it was demonstrated, that Aurora $\mathrm{C}$ plays a role in cell cycle progression, while the Aurora B role is restricted to maintaining of SAC (spindle assembly checkpoint) [16]. The functional role of AURKC in cancer is not well understood yet, but an increase of its levels in tumors is frequently associated with cell proliferation, migration and bad prognosis. Overexpression of Aurora C in NIH-3T3 cell lines results in abnormal cell division, centrosome amplification and appearance of multi-nuclear cells [17]. Those events are strongly associated with malignant transformation, therefore, the AURKC gene was considered as oncogene and Aurora $\mathrm{C}$ is a potential target for anticancer therapy [6].

Although increased levels and hyperactivity of kinases from the Aurora family are usually reported to be associated with tumor development and progression, and also with poor prognosis, there are few reports, confirming this idea in a case of PCa. For example, it was shown by immunostaining that AURKA, AURKB and AURKC were significantly reduced in PCa tissues, compared with cells of prostate nodular benign hyperplasia. However, no significant differences in gene expression were found at mRNA levels. This could be explained by mutations in genes, encoding Aurora kinases [18]. From the other hand, it was shown that Aurora A and B are expressed at higher levels in precancerous lesions and $\mathrm{PCa}$ of different stages, compared with non-cancerous tissues [19].

Therefore, the aim of our research was to examine the expression of Aurora kinase genes at the 
mRNA level in PCa, surrounding non-cancerous prostate tissue and benign prostate tumors (adenomas). Also, we wanted to investigate whether there is any correlation between expression of AURK genes with presence or absence of a TMPRSS2-ERG fusion transcript, PTEN status and also expression of prostate cancer-associated genes (PCAG) [20-22]. We believe, our study will shed some light on the role of Aurora kinases in PCa development.

\section{Materials and Methods}

A collection of prostate tissues samples. Samples of cancer tissue and paired conventional normal tissue (CNT) (at an opposite side of tumor) were frozen in liquid nitrogen immediately after surgical resection, performed at the National Cancer Institute (Kyiv, Ukraine). Benign prostate tumors (prostate adenoma samples) were collected at the Institute of Urology (Kyiv, Ukraine) after radical prostatectomy; samples were frozen in liquid nitrogen, as described above. All the samples were collected in accordance with the Declaration of Helsinki and the guidelines, issued by an Ethics Committee of the Institute of Urology, the National Cancer Institute and the Ethics Committee of the Institute of Molecular Biology and Genetics (protocol number: 16, December 3, 2018). Altogether, 33 samples of prostate adenocarcinoma of different Gleason score and stages, 33 paired CNT samples and 17 samples of benign prostate tumors (adenomas) were collected and analyzed. Tumor samples were characterized, according to an International System of Classification of Tumors and the World Health Organization (WHO) criteria. Clinical and pathological characteristics (CPCs) of PCa samples are presented in Table 1. The presence and/ or absence of a TMPRSS2/ERG fusion was detected earlier in our laboratory for the same cohort of patients [20].

Total RNA isolation and cDNA synthesis. 50$70 \mathrm{mg}$ of frozen tissues were mashed to a powder in the liquid nitrogen. Total RNA was extracted by TRI-reagent (SIGMA), according to the manufacturer's protocol. The total RNA concentration was analyzed by a spectrophotometer (NanoDrop Tech Experimental technologies Inc., USA). The quality of the total RNA was determined in a $1 \%$ agarose gel by band intensity of 28S and 18S rRNA (28S/18S ratio). cDNA was synthesized from $1 \mu \mathrm{g}$ of the total RNA, following by treatment with RNase free DNase I (Thermo Fisher Scientific, USA), using RevertAid H-Minus M-MuLV Reverse Transcriptase
(Thermo Fisher Scientific, USA), according to the manufacturer's protocol.

Quantitative polymerase chain reaction ( $q P C R)$. Gene expression levels of Aurora kinases genes (AURKA, AURKB and AURKC) were detected by qPCR, using HOT FIREPol EvaGreen qPCR Mix Plus (Solis BioDyne, Estonia) and CFX96 Real-Time PCR Detection System (Bio-Rad, USA) under the following conditions: $95{ }^{\circ} \mathrm{C}-12 \mathrm{~min}$, following 40 cycles of $95{ }^{\circ} \mathrm{C}-15 \mathrm{~s}, 60^{\circ} \mathrm{C}-20 \mathrm{~s}$, elongation $72{ }^{\circ} \mathrm{C}-20 \mathrm{~s}$. Sequences of primers for AURKA, AURKB and AURKC genes were described in [23]. TBP has been used as reference gene for relative quantification [21]. $2^{-\Delta \mathrm{CT}}$ and $2^{-\Delta \Delta \mathrm{CT}}$ methods, described earlier [21], were used for the relative gene expression (RE) level calculation and analysis.

Statistical analysis. The Kolmogorov-Smirnov test was used to analyze the normality of distribution. The Kruskal-Wallis test and Dunn-Bonferroni post hoc test were performed to determine RE differences between pairs of sample groups under multiple comparisons in $2^{-\Delta \mathrm{Ct}}$. The Wilcoxon Matched Pairs test was performed to compare RE in prostate adenocarcinoma and paired CNT. RE fold differences in $2^{-\Delta \Delta C t}$ model were considered significant when expression changes were more than 2-fold. The Fisher exact test was performed to monitor differences between sample groups. The Spearman's rank correlation test was used to find the putative correlations between RE and CPCs of prostate tumors and also correlations between RE of the studied genes. All calculations were performed, using a STATISTICA 10 software.

\section{Results and Discussion}

$\mathrm{RE}$ of genes, encoding Aurora kinases (AURKA, $A U R K B, A U R K C)$ was detected in prostate adenocarcinomas $(T)$, paired conventionally normal prostate tissues $(\mathrm{N})$ and benign prostate tumors (adenomas) (A), see Fig. 1. Expression of AURK genes in peripheral blood of healthy donors served as an additional positive control (red column, Fig. 1).

The statistical analysis of the obtained data did not support the Gaussian distribution of RE of the studied genes in all groups. Therefore, we used nonparametric criteria for further analysis.

Since Aurora kinases are considered as potential oncogenes, we were aimed to investigate the difference in AURK genes' expression in malignant and conditionally normal prostate tissues taken from the same patient. For that reason, we compared the RE of AURKA, AURKB and AURKC using the Wil- 

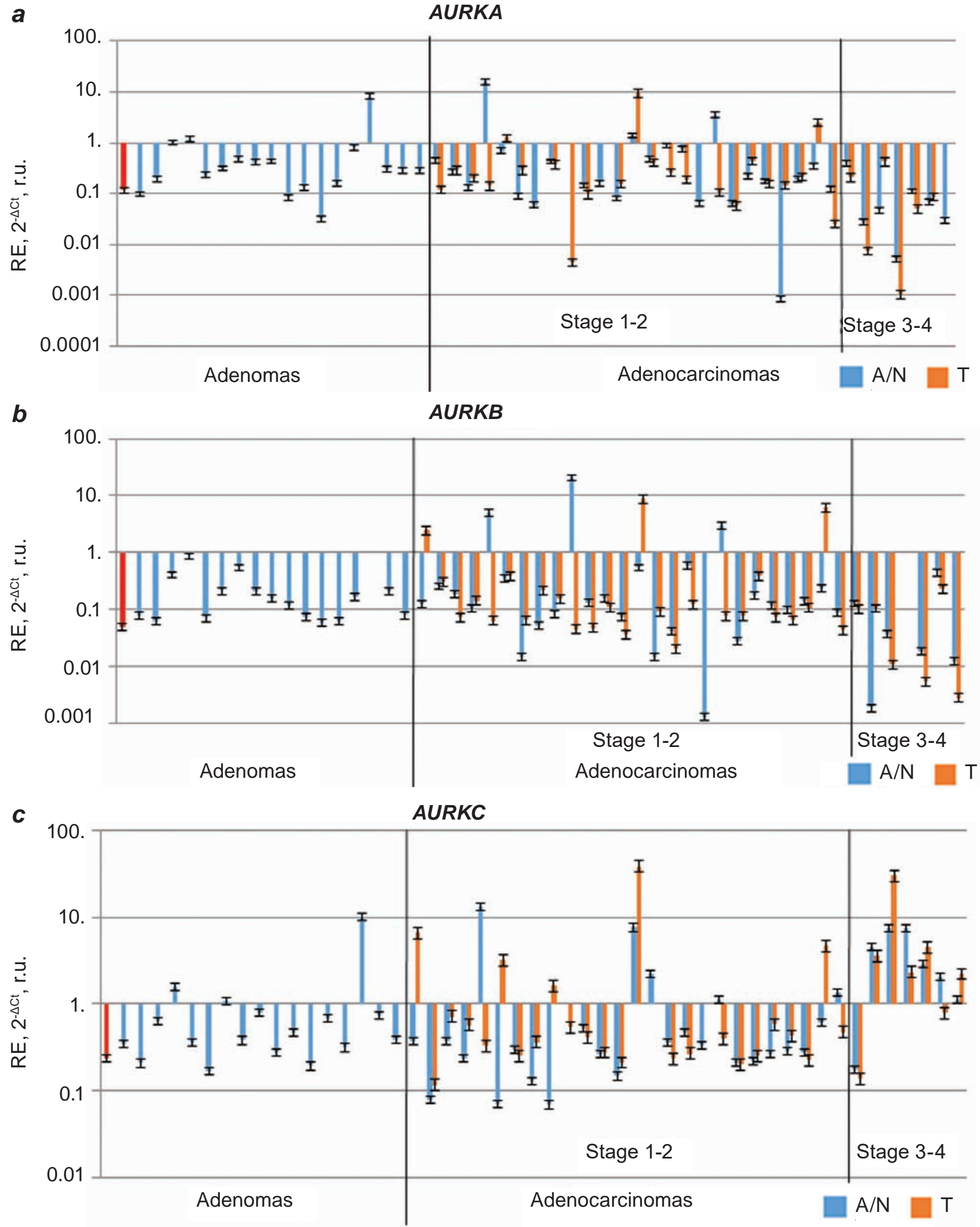

Fig. 1. Relative expression (RE) of AURKA (a), AURKB (b) and AURKC (c) in adenocarcinomas, conventionally normal prostate tissues and benign prostate tumors (adenomas). T/N pairs were distributed, according to the stage advancement. Adenomas were placed randomly. In legend: A - adenomas: $N$ - conventionally normal prostate tissue; $T$ - adenocarcinoma. The first column (in red) - RE of AURK genes in peripheral blood (an additional control) 
coxon Matched Pairs Test applied to $33 \mathrm{~T} / \mathrm{N}$ pairs. However, no significant differences have been found between $\mathrm{T}$ and $\mathrm{N}$ samples.

Next, we examined RE of AURK genes, comparing these values in malignant (tumors) and nonmalignant (conventionally normal tissues and adenomas) lesions. The significant differences in RE were found for AURKA in tumors and adenomas $(P=0.047)$, with lower expression in tumors (Fig. 2, $a(1)$ ). We proposed then that more pronounced differences may be expected by taking into account tumor stages as this is a tumor characteristic known as the most clinically valuable one. For this purpose, the samples have been divided into 5 groups: tumors at stages $1 / 2$ and $3 / 4$ (T1/2 and T3/4 respectively), paired normal samples called N1/2 and N3/4 depending on the tumor samples and adenoma samples called A (Fig. 2). The difference in RE of Aurora kinases genes was analyzed based on the calculations using Kruskal-Wallis test and Multiple comparison test (Dunn-Bonferroni post hoc method). As one can see in Fig. 2, a(2), RE of AURKA gene is much lower in tumors at the stage $3-4$, than that in adenoma tissues $(P=0.036)$. When comparing the expression of $A U R K C$ gene, the N1/2 and N3/4 groups have different expressions with higher value corresponding to N3/4 tissues ( $P=0.021$ ). Finally, no differences between the groups under investigation were observed for $A U R K B$ expression.

Considering in addition another important prostate cancer characteristic called Glisson score (GS), we found no differences between the high and low GS samples in expression of Aurora kinase genes.

It is well known that the deviations in cell division processes can lead to genomic rearrangements and the formation of gene fusions. In particular, this concerns the expression of fusion transcripts, some of which were described for their carcinogenic effect. Previously we have reported [17] about the presence of the most common prostate cancer fusion transcript, TMPRSS2-ERG, observed in the investigated samples [17]. Here the samples were grouped according to the presence or absence in them of TMPRSS2-ERG fusion transcript, $\mathrm{T}$ and $\mathrm{N}$ with fusion ( $\mathrm{F}+$ ); $\mathrm{T}$ and $\mathrm{N}$ without fusion (F-), respectively. Their comparison with each other and with adenomas by using the Kruskal-Wallis and the multiple comparison (Dunn-Bonferroni post hoc method) tests characteristics allows us to make a conclusion about lower AURKA expression in $\mathrm{F}$ - tumor samples when compared to adenoma samples ( $P=0.0325)$. No other significant differences in expression were observed for fusion transcript positive and negative samples.

PTEN levels were assessed in these samples earlier as well [18]. So, T, N and A samples were divided into groups with the low and high PTEN expression. We found that AURKA expression in adenocarcinomas with high $P T E N$ levels was significantly lower than in adenomas with low PTEN levels $(P=0.033)$.

To establish an unchanged expression level, we analyzed RE of AURK genes in early stage conventional normal tissues (N1/2), advanced stages conventional normal tissues (N3/4) and adenomas. We consider that only N1/2 and adenoma samples have normal unchanged RE in AURK genes. It was resolved to admit those values as average unchanged expression level of studied genes in prostate tissue. We estimated changes in RE of AURKA, AURKB and $A U R K C$ expression compared to taken average unchanged RE.

In T3-4 group, 63\% had more than 2-fold lower expression of AURKA and AURKB compared to average unchanged RE, among which $50 \%$ of samples even had more than 3-fold lower expression of those genes. In contrast, level of AURKC expression in the same groups was higher than average unchanged expression of this gene. Compared to it, in $75 \%$ of samples from T3-4 group we detected 2-fold higher AURKC RE. Moreover, 3-fold higher levels of AURKC occurred in $63 \%$ of samples from this group. For N3-4 group the changes were even more pronounced: $87.5 \%$ of those samples have more than 3-fold higher expression of AURKC in comparison with average unchanged expression level. Summarizing, the group of conventionally normal tissues from patients with high tumor stage (N3-4), but not the tumor tissues from those patients (T3-4) demonstrated the strongest alterations in expression of AURKA and AURKC genes.

Correlation of AURK gene expression with clinical and pathological characteristics. Spearman rank correlation analysis of AURK genes expression with clinical and pathological characteristics of patients (Glisson score, stage, PSA level, age, fusion status and PTEN relative expression) in adenocarcinoma group demonstrated the presence of correlation only between AURKB and AURKC expression and the stage of the disease (Table 1). We found the negative correlation between stage and AURKB ex- 

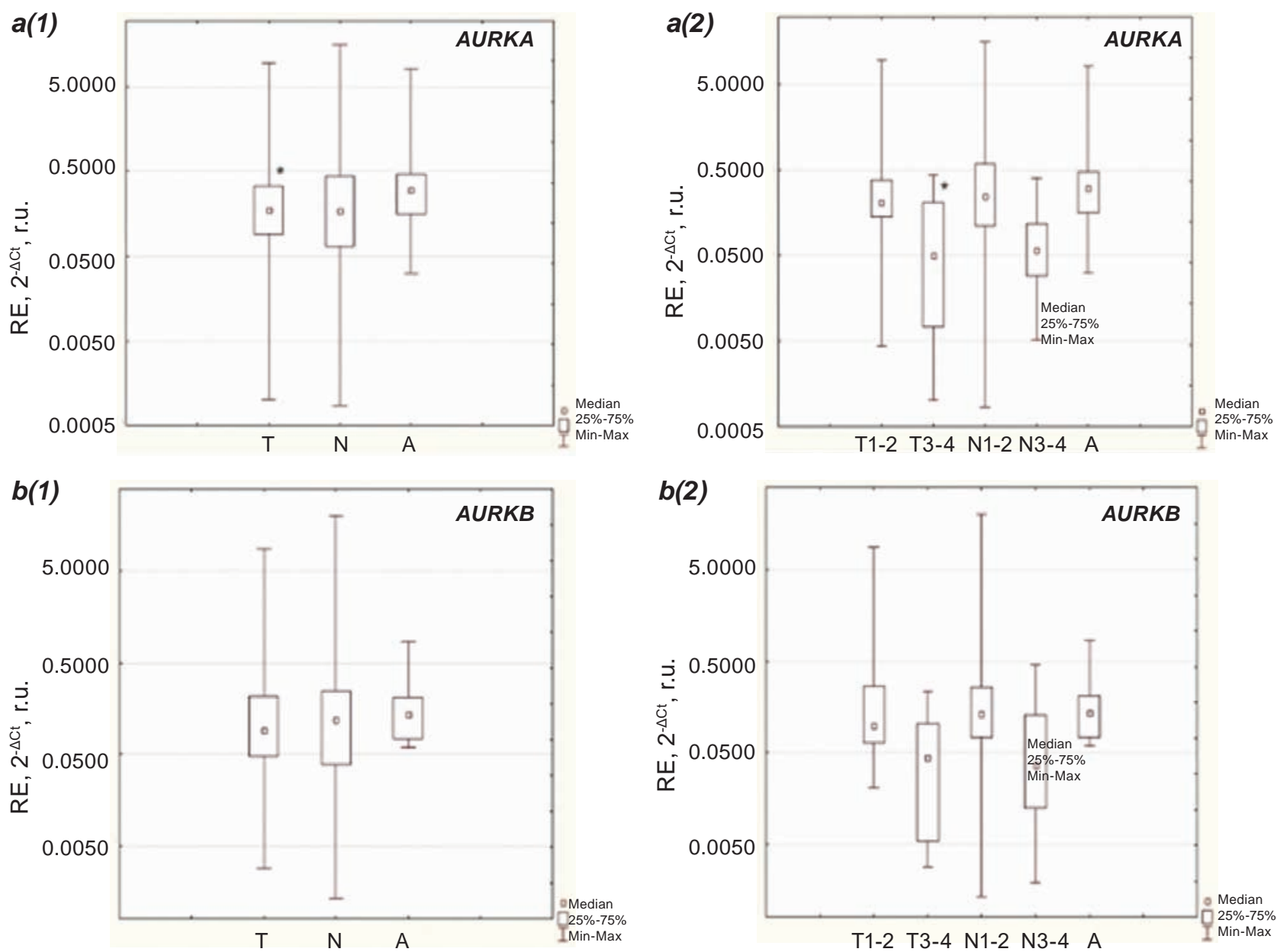

c(1)

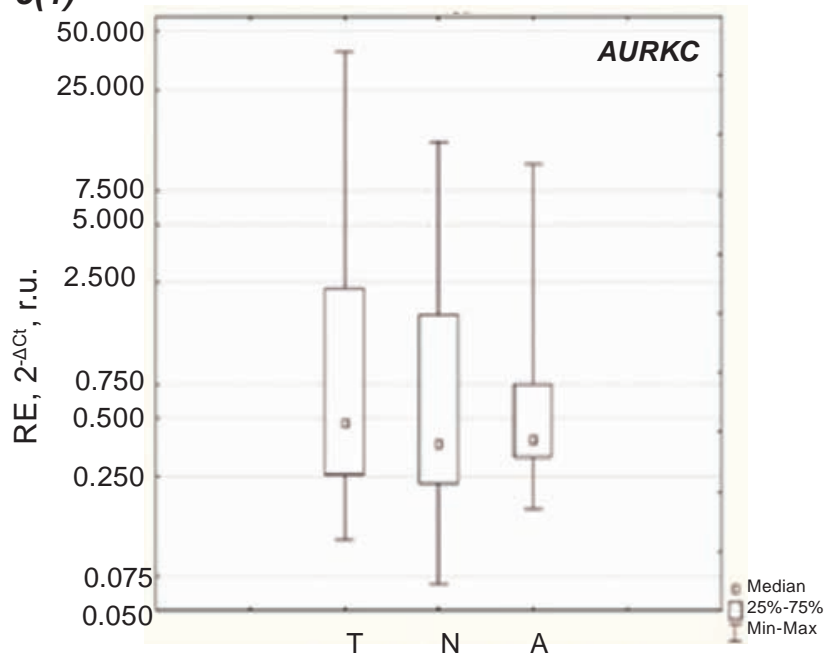

c(2)

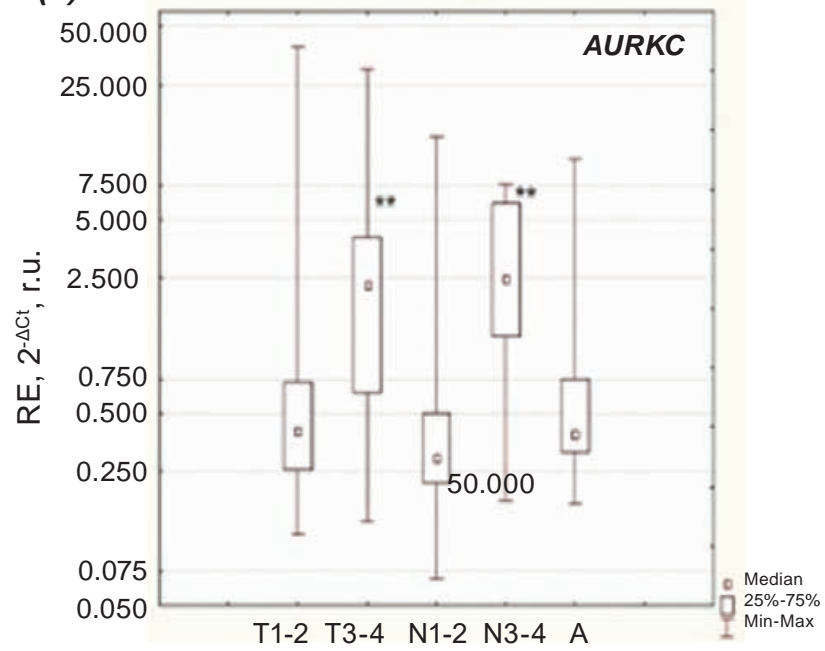

Fig. 2. Differences in RE of AURK A, AURKB and AURKC in adenocarcinomas, conventionally normal prostate tissues and benign prostate tumors (adenomas). $\boldsymbol{a}$ - AURKA expression; $\boldsymbol{b}$ - AURKB expression; $\boldsymbol{c}-$ AURKC expression; 1 - samples were grouped into 3 groups: cancer tissue $(T)$, paired conventional normal tissues (N) and adenomas (A); 2 - samples were grouped into 5 groups, based on the stage of disease: the stage 1 and 2 (T1-2), the stage 3 and 4 (T3-4), paired conventional normal tissues from patients with the stage 1 and 2 tumors (N1-2), paired conventional normal tissues from patients with the stage 3 and 4 tumors (N3-4), and adenomas (A). *Significant RE differenced in T comparing to A; **significant RE differenced in T1-2 and N1-2 comparing to T3-4 and N 3-4 accordingly 
Table 1. Correlation between CPC and AURK gene expression ( $r^{s}$ values)

\begin{tabular}{l|c|c|c}
\hline \multirow{2}{*}{\multicolumn{1}{c|}{ CPC }} & \multicolumn{3}{|c}{ Genes } \\
\cline { 2 - 4 } & AURKA & AURKB & AURKC \\
\hline GS & -0.093 & -0.219 & 0.119 \\
Stage & -0.201 & $-0.344^{*}$ & $0.372^{*}$ \\
PSA ng/ml & -0.067 & 0.010 & 0.039 \\
Age & -0.026 & 0.176 & 0.204 \\
Fusion status & 0.278 & 0.106 & -0.056 \\
PTEN RE & 0.142 & -0.112 & -0.020 \\
\hline
\end{tabular}

Note: ${ }^{*} P<0.01$

pression $\left(r^{s}=-0.344, P<0.05\right)$ in adenocarcinoma group. Expression of AURKC, however, correlated with stage positively $\left(r^{s}=0.372, P<0.05\right)$. Thus, here we observe increasing of AURKC expression with tumor progression, accompanied by decreasing of $A U R K B$ RE level in high-grade tumors.

Correlation of RE of AURK A, B, C and levels of prostate cancer-associated genes. Spearman rank correlation analysis of AURK genes RE have shown a significant correlation between AURKB and AURKA genes in T $\left(r^{s}=0.365, P<0.05\right)$. Expression of $P C A G$ genes, previously studied in our group [18, 19], also correlated with expression of the Aurora kinases genes in adenocarcinoma group (Table 2). Levels of AR 1 isof, CASP3 and OCLN correlated positively with expression of AURKA. AURKB expression positively correlated with $V D R$ levels. RE of MKI67 and NKX3.1 correlated with both, the AURKA and AURKB, but not with the AURKC expression. Of note, $A U R K C$ expression positively

Table 2. Correlation between expression of EMT and AURK genes ( $r^{s}$ values)

\begin{tabular}{l|c|c|c}
\hline \multirow{2}{*}{$\begin{array}{c}\text { PCAG } \\
\text { genes }\end{array}$} & \multicolumn{3}{|c}{ AURK genes } \\
\cline { 2 - 4 } AR 1 isof & AURKA & AURKB & AURKC \\
CASP3 & $0.561^{*}$ & 0.331 & -0.109 \\
MKI67 & $0.561^{* *}$ & 0.234 & 0.065 \\
NKX3.1 & $0.358^{* *}$ & $0.647^{*}$ & -0.025 \\
OCLN & $0.355^{* *}$ & 0.210 & -0.113 \\
VDR & 0.296 & $0.488^{*}$ & 0.025 \\
INSR A & 0.162 & 0.006 & $-0.397^{* *}$ \\
CYP17A1 & 0.104 & 0.159 & $0.370^{* *}$ \\
\hline
\end{tabular}

Note: ${ }^{*} P<0.01,{ }^{* *} P<0.05$ correlated with CYP17A1 $\left(r^{s}=0.370, P<0.05\right)$ and negatively with INSRA levels ( $r^{\mathrm{s}}=-0.397, P<0.05$ ).

As was already mentioned above, PCa is the extremely heterogeneous disease at the level of organ, patient and population [24]. Despite the appreciable amount of investigations on prostate cancer nowadays, the data reported on the expression of Aurora kinases in PCa cell lines and clinical samples are incomplete and contradictory so far.

Here we stress first of all that the absence of differences between tumor and normal pairs from the patients with prostate cancer can be explained by pathological processes in normal surrounding tissues in a case of aberrant signals from tumor cells and microenvironment. However, those tissues are closely connected with tumor and cannot be treated as absolutely normal. Based on our results, one can conclude about the presence of pathological alterations in those samples rather than the absence of differences between malignant and non-malignant tissues [25, 26].

Significantly higher levels of AURKA mRNA in adenomas tissues, which often carry out inflammatory process, is explained by the studied property of Aurora A to participate actively in inflammation. One of the possible ways for Aurora A to induce carcinogenesis is namely through promotion of $I \kappa B \alpha-$ mediated activation of NFKB [27]. Therefore, high levels of AURKA transcripts in adenomas can be the part of intensive inflammation process. During tumor development, cancer cells have already a great amount of different phenotypes with various genomic and epigenetic alterations, resulting in their uncontrolled proliferation and survival. We hypothesize, that they acquire another intensive stimulus for proliferation and, consequently, in high stage tumors, the primary drivers of cell division lose their position and express at lower levels. Nevertheless, we should take into account that we observe these results only at the mRNA level, but we did not check the presence of the protein products in studied samples. Stability of Aurora A and B is neatly regulated by ubiquitination and proteosome degradation [28]. Ubiquitination is often disrupted in cancer cells, leading to inappropriate degradation of key tumorigenesis players [29]. Thus, lower levels of mRNA do not always imply low levels of active proteins, that will be an issue of further investigations.

Aurora A is one of kinases which phosphorylate androgen receptors (ARs) at Thr282/Ser293 residues, regarding to the transactivation domain. Con- 
sequently, it should result in overexpression of genes from AR axis [30], but was not evidently connected with overexpression of $A R$ gene. Jones et al. [31] demonstrated a direct influence of Aurora kinase A on constitutively active variant of androgen receptor, $A R-V 7$, expression and regulation of its splicing. However, these data do not explain the calculated correlation between expression of $A R 1$ isof and AURKA. Nevertheless, it allows us to make suggestions about the possibility of the mutual regulation of these genes.

OCLN gene, the common marker of normal epithelial cells, encodes occludin, the protein, which involved in disruption of tight junctions and actin reorganization [32]. Aurora A kinase also acts in a similar manner, participating in structural changes in actin filaments and lamellipodia formation [33]. Correlation between OCLN and AURKA genes' expression can occur because of involvement of their products in the same cellular processes, e.g. enhancing cells motility and migration. Co-regulation or mutually adjustment of their expression should be further investigated. However, elevated levels of transcripts of those genes and/or their protein products can potentially serve as marker of metastatic and invasive phenotype of such tumor.

In our results, expression of Aurora kinases A and B genes positively correlated both with MKI67 and NKX3.1 expression. As MKI67 encodes marker of proliferation KI67 and commonly reported to be expressed together with other proliferation markers (which includes Aurora kinases' genes) [34], we suppose that our results confirm previous data. On the other hand, NKX3.1 is a well-known tumor suppressor gene, which encodes NK3 homeobox 1 (NKX3.1) protein. Expression of NKX3.1 is common for normal epithelial cells. It is one of the AR target genes and is often loss in prostate cancer. Moreover, NKX3.1 and AR proteins directly regulate each other in a feed-forward regulatory loop [35]. Some controversial features in the behavior of the present results can be attributed to upregulation of AR expression by Aurora A kinase. Elevated amounts of androgen receptor cause increased expression of NKX3.1 gene. It might be an ordinary cellular response to intensive proliferation, i.e. NKX3.1 is used as a "gate-keeper" to block cell proliferation [36]. In cells where expression of NKX3.1 is not loss via deletions or methylation of its promoter, expression of this gene can be increased proportionally in answer to abnormal proliferation.
A mutual regulation for AURKA and AURKB gene expressions by c-Myc was reported previously by Hollander et al. [37]. As one can easily see, our results, demonstrating positive correlation between AURKA and AURKB transcript levels in prostate tissues, support previous observations and can be accordingly explained by mutual regulation of AURKA and $A U R K B$ gene expressions.

Expression of AURKB did not exhibit any significant differences between the groups of samples. However, different mechanisms can be used to explain negative correlation between expression of Aurora B gene with tumor stage and decreased level of its transcript (similarly to AURKA), compared to unchanged average expression level, in high stage tumors.

At first, cells, deficient of crucial cell division regulator, may acquire a great amount of mutations, and decreased $A U R K B$ expression can be not the consequence or feature of high grade tumor, but the driver and reason of tumor progression. Secondly, overlapping function of Aurora C and Aurora B can explain positive correlation of AURKC and negative of $A U R K B$ with tumor stage. Unfortunately, the methods used in the present work do not give access to unambiguous conclusion concerning the mechanism of gene correlations.

Strong positive correlation between AURKB and VDR (Vitamin D receptor) genes' expression we explained as example of two independent coexisting processes in prostate cancer development. Both of them are connected with tumor stage. It was previously reported, that high level of VDR protein product is associated with lower tumor stage and more favorable prognosis for prostate cancer patients [38]. In our opinion, it could be two indirectly connected events in PCa.

We also found the positive correlation between AURKC expression and tumor stage and expression of CYP17A1. CYP17A1 encodes a member of the cytochrome P450 superfamily of enzymes, steroid hydroxylase enzyme, which is essential for steroid hormone production. In normal physiological conditions, expression of this enzyme is observed only in few tissues, namely liver, testes and uterus. Increased levels of CYP17A1 mRNA and protein product have been found in prostate cancer [39]. Being steroidogenic enzyme, CYP17A1 is strongly associated with castration resistant PCa (CRPC) development [40]. At the same time, RE of AURKC negatively correlated with relative expression of INSRA gene, which 
is also associated with epy development of CRPC. It encodes oncogenic isoform of insulin receptor and activates cellular pathways in response to binding with insulin-like growth factor (IGF) or insulin. Binding with both ligands promotes cell growth, proliferation and avoidance of apoptosis [41]. It is suggested that INSRA signaling is one of the possible mechanism of androgen-independent PCa development [42]. On the other hand, expression of steroidogenic enzymes, such as CYP17A1, are also regarded to CRPC [40]. We propose that here we observe two mutually exclusive directions of PCa progression to CRPC.

Some decades ago, it was shown the existence of the meiotic specific genes, which are activated in mitotically dividing somatic cells and become the powerful drivers of carcinogenesis. Such deviations contribute to illegitimacy in chromosome segregation and exchange of genetic material, aneuploidy and other cell division failures, which can produce different populations of tumor cells. Aurora kinase $\mathrm{C}$ and CYP17A1 are two proteins that are active in germ cells, and they are putative oncogenes. Co-expression of them in PCa supports a soma-togermline oncogenic model of carcinogenesis. This model arose as an alternative to embryologic theory of cancer and explained several aspects, which could not be explained by stem cell-like model, e.g. abnormal mitosis, rapid genomic and epigenetic evolution, altered DNA repair, chromosomal end protection, etc. [43].

We demonstrated that AURKA and AURKC are differentially expressed in $\mathrm{PCa}$, compared with ade ${ }^{-}$ noma, especially at advance stages of the disease. Beside an altered expression pattern of AURK in prostate cancers, we also found a correlation of their expression and different molecular characteristics of tumors, and with prostate cancer-associated genes. Our data suggest that genes, encoding Aurora kinases, could be involved in prostate carcinogenesis.

Funding. This work was funded by the State Budget Program "Support for the Development of Priority Areas of Scientific Research" (Code: 6541230) and National Academy of Sciences of Ukraine in a frame of budget topic "Identification of novel biomarkers for diagnostics of malignancies ad development of gene therapy approaches using model systems"

Acknowledgements. We thank Dr. Elena Kashuba and Dr. Sergiy Mankovsky for their great support in preparing the text of the manuscript.
Conflict of interest. Authors have completed the Unified Conflicts of Interest form at http://ukrbiochemjournal.org/wp-content/uploads/2018/12/ coi_disclosure.pdf and declare no conflict of interest.

\section{АНАЛІЗ ЕКСПРЕСІЇ ГЕНІВ КІНАЗ РОДИНИ AURORA ВКАЗУС НА ЇХНЮ РІЗНУ РОЛЬ В РОЗВИТКУ РАКУ ПЕРЕДМІХУ РОВОЇ ЗАЛОЗИ}

\section{О. С. Маньковська ${ }^{1 凶}$, Г. В. Геращенко Є. Е. Розенберг ${ }^{1}$ Е. О. Стаховськийㄱ, О. А. Кононенко, Ю. Н. Бондаренко B. I. Камуба ${ }^{1,4}$}

${ }^{1}$ Інститут молекулярної біології і генетики НАН України, Київ;

${ }^{2}$ Націнальний інститут раку, Міністерство охорони здоров’я України, Київ;

${ }^{3} Д У$ «Інститут урології НАМН України», Київ;

${ }^{4}$ Відділ мікробіології, онкології та клітинної біології, Каролінський інститут, Стокгольм, Швеція; e-mail: mankovsska@gmail.com

Кінази Aurora A і В відіграють важливу роль у регуляції мітозу, тоді як Aurora C контролює мейотичний поділ. Ці протеїни проявляли суперечливу поведінку за розвитку епітеліальних пухлин. Нашою метою було дослідити, чи існують відмінності в експресії генів кіназ родини Aurora в злоякісних та незлоякісних пухлинах та непухлинних тканинах; порівняти їх експресію 3 клінічними характеристиками пацієнтів та експресією інших генів, пов'язаних із раком передміхурової залози. Кількісну RT-PCR було використано для визначення експресії генів Aurora A-C у 33 аденокарциномах передміхурової залози (Т), в парних умовно нормальних тканинах (N) та 17 аденом (А). Значення відносної експресії (BE) для досліджуваних генів оцінювали за допомогою $2^{-\Delta \mathrm{Ct}} \mathrm{Ta} 2^{-\Delta \Delta \mathrm{Ct}}$ методу. Для статистичного аналізу було використано тест Крускала-Уолліса з корекцією на множинні порівняння згідно 3 процедурою Бенджаміна-Хохберга 3 $\mathrm{FDR}=0,2$, post hoc тест Данна-Бонферроні та аналіз кореляцій за Спірманом. Як виявилося, значення RE для AURKA були значно нижчими в зразках групи T порівняно 3 групою А. Крім того, виявлено значне зростання рівнів експресії AURKC для Т3-4 стадії порівняно з Т1-2 стадією. Значення BE AURKC у Т-групі корелювали зі стадією пухлини, тоді як BE AURKB демонстру- 
вала негативну кореляцію зі стадією пухлини. Також виявлено значну кореляцію між рівнями експресії генів $A U R K$ та генами, пов'язаними 3 раком передміхурової залози, в групі аденокарцином. Зроблено припущення, що одержані дані вказують на ймовірне залучення генів кіназ родини Aurora в канцерогенез передміхурової залози.

К л ю ч о в і с ло в а: рак передміхурової залози, кінази родини Aurora, гени EMT, злитий транскрипт TMPRSS2-ERG, експресія PTEN.

\section{References}

1. Tolkach Y, Kristiansen G. The Heterogeneity of Prostate Cancer: A Practical Approach. Pathobiology. 2018; 85(1-2): 108-116.

2. Cancer Genome Atlas Research Network. The Molecular Taxonomy of Primary Prostate Cancer. Cell. 2015; 163(4): 1011-1025.

3. Jaratlerdsiri W, Chan EKF, Petersen DC, Yang C, Croucher PI, Bornman MSR, Sheth P, Hayes VM. Next generation mapping reveals novel large genomic rearrangements in prostate cancer. Oncotarget. 2017; 8(14): 23588-23602.

4. Do TV, Hirst J, Hyter S, Roby KF, Godwin AK. Aurora A kinase regulates non-homologous end-joining and poly(ADP-ribose) polymerase function in ovarian carcinoma cells. Oncotarget. 2017; 8(31): 50376-50392.

5. Kalsbeek D, Golsteyn RM. G2/M-phase checkpoint adaptation and micronuclei formation as mechanisms that contribute to genomic instability in human cells. Int $\mathrm{J} \mathrm{Mol}$ Sci. 2017; 18(11). pii: E2344.

6. Tang A, Gao K, Chu L, Zhang R, Yang J, Zheng J. Aurora kinases: novel therapy targets in cancers. Oncotarget. 2017; 8(14): 23937-23954.

7. Lindon C, Grant R, Min M. Ubiquitin-Mediated Degradation of Aurora Kinases. Front Oncol. 2016; 5: 307.

8. Fu J, Bian M, Jiang Q, Zhang C. Roles of Aurora kinases in mitosis and tumorigenesis. Mol Cancer Res. 2007; 5(1): 1-10.

9. Lehman NL, O'Donnell JP, Whiteley LJ, Stapp RT, Lehman TD, Roszka KM, Schultz LR, Williams CJ, Mikkelsen T, Brown SL, Ecsedy JA, Poisson LM. Aurora A is differentially expressed in gliomas, is associated with patient survival in glioblastoma and is a potential chemotherapeutic target in gliomas. Cell Cycle. 2012; 11(3): 489502.
10. Kamada K, Yamada Y, Hirao T, Fujimoto H, Takahama Y, Ueno M, Takayama T, Naito A, Hirao S, Nakajima Y. Amplification/overexpression of Aurora-A in human gastric carcinoma: potential role in differentiated type gastric carcinogenesis. Oncol Rep. 2004; 12(3): 593-599.

11. Krenn V, Musacchio A. The Aurora B Kinase in Chromosome Bi-Orientation and Spindle Checkpoint Signaling. Front Oncol. 2015; 5: 225.

12. Shrestha RL, Conti D, Tamura N, Braun D, Ramalingam RA, Cieslinski K, Ries J, Draviam VM. Aurora-B kinase pathway controls the lateral to end-on conversion of kinetochoremicrotubule attachments in human cells. Nat Commun. 2017; 8(1): 150.

13. Chieffi P, Cozzolino L, Kisslinger A, Libertini S, Staibano S, Mansueto G, De Rosa G, Villacci A, Vitale M, Linardopoulos S, Portella G, Tramontano D. Aurora B expression directly correlates with prostate cancer malignancy and influence prostate cell proliferation. Prostate. 2006; 66(3): 326-333.

14. Kimura M, Matsuda Y, Yoshioka T, Okano Y. Cell cycle-dependent expression and centrosome localization of a third human aurora/Ipl1-related protein kinase, AIK3. J Biol Chem. 1999; 274(11): 7334-7340.

15. Yan X, Cao L, Li Q, Wu Y, Zhang H, Saiyin H, Liu X, Zhang X, Shi Q, Yu L. Aurora C is directly associated with Survivin and required for cytokinesis. Genes Cells. 2005; 10(6): 617626.

16. Quartuccio SM, Schindler K. Functions of Aurora kinase $\mathrm{C}$ in meiosis and cancer. Front Cell Dev Biol. 2015; 3: 50.

17. Khan J, Ezan F, Crémet JY, Fautrel A, Gilot D, Lambert M, Benaud C, Troadec MB, Prigent C. Overexpression of active Aurora-C kinase results in cell transformation and tumour formation. PLoS One. 2011; 6(10): e26512.

18. Nna E, Madukwe J, Egbujo E, Obiorah C, Okolie C, Echejoh G, Yahaya A, Adisa J, Uzoma I. Gene expression of Aurora kinases in prostate cancer and nodular hyperplasia tissues. Med Princ Pract. 2013; 22(2): 138-143.

19. Lee EC, Frolov A, Li R, Ayala G, Greenberg NM. Targeting Aurora kinases for the treatment of prostate cancer. Cancer Res. 2006; 66(10): 49965002. 
20. Mevs LV, Gerashchenko GV, Rosenberg EE, Pikul MV, Marynychenko MV, Gryzodub OP, Vozianov SO, Stakhovsky EA, Kashuba VI. Detection of prostate specific ETS fusion transcripts in cancer samples. Biopolym Cell. 2017; 33(4): 256-267.

21. Gerashchenko GV, Mankovska OS, Dmitriev AA, Mevs LV, Rosenberg EE, Pikul MV, Marynychenko MV, Gryzodub OP, Stakhovsky EO, Kashuba VI. Expression of epithelialmesenchymal transition-related genes in prostate tumours. Biopolym Cell. 2017; 33(5): 335-355.

22. Gerashchenko GV, Mevs LV, Chashchina LI, Pikul MV, Gryzodub OP, Stakhovsky EO, Kashuba VI. Expression of steroid and peptide hormone receptors, metabolic enzymes and EMT-related genes in prostate tumors in relation to the presence of the TMPRSS2/ERG fusion. Exp Oncol. 2018; 40(2): 101-108.

23. Baldini E, Arlot-Bonnemains Y, Sorrenti S, Mian C, Pelizzo MR, De Antoni E, Palermo S, Morrone S, Barollo S, Nesca A, Moretti CG, D'Armiento M, Ulisse S. Aurora kinases are expressed in medullary thyroid carcinoma (MTC) and their inhibition suppresses in vitro growth and tumorigenicity of the MTC derived cell line TT. BMC Cancer. 2011; 11: 411.

24. Shoag J, Barbieri CE. Clinical variability and molecular heterogeneity in prostate cancer. Asian J Androl. 2016; 18(4): 543-548.

25. Egeblad M, Nakasone ES, Werb Z. Tumors as organs: complex tissues that interface with the entire organism. Dev Cell. 2010; 18(6): 884-901.

26. Aran D, Camarda R, Odegaard J, Paik H, Oskotsky B, Krings G, Goga A, Sirota M, Butte AJ. Comprehensive analysis of normal adjacent to tumor transcriptomes. Nat Commun. 2017; 8(1): 1077.

27. Briassouli P, Chan F, Savage K, Reis-Filho JS, Linardopoulos S. Aurora-A regulation of nuclear factor-kappaB signaling by phosphorylation of IkappaBalpha. Cancer Res. 2007; 67(4): 16891695.

28. Willems E, Dedobbeleer $M$, Digregorio $M$, Lombard A, Lumapat PN, Rogister B. The functional diversity of Aurora kinases: a comprehensive review. Cell Div. 2018; 13 : 7.

29. Senft D, Qi J, Ronai ZA. Ubiquitin ligases in oncogenic transformation and cancer therapy. Nat Rev Cancer. 2018; 18(2): 69-88.

30. Shu SK, Liu Q, Coppola D, Cheng JQ. Phosphorylation and activation of androgen receptor by Aurora-A. J Biol Chem. 2010; 285(43): 33045-33053.

31. Jones D, Noble M, Wedge SR, Robson CN, Gaughan L. Aurora A regulates expression of AR-V7 in models of castrate resistant prostate cancer. Sci Rep. 2017; 7: 40957.

32. Suárez-Causado A, Caballero-Díaz D, Bertrán E, Roncero C, Addante A, García-Álvaro M, Fernández M, Herrera B, Porras A, Fabregat I, Sánchez A. HGF/c-Met signaling promotes liver progenitor cell migration and invasion by an epithelial-mesenchymal transition-independent, phosphatidyl inositol-3 kinase-dependent pathway in an in vitro model. Biochim Biophys Acta. 2015; 1853(10 Pt A): 2453-2463.

33. Wang LH, Xiang J, Yan M, Zhang Y, Zhao Y, Yue CF, Xu J, Zheng FM, Chen JN, Kang Z, Chen TS, Xing D, Liu Q. The mitotic kinase Aurora-A induces mammary cell migration and breast cancer metastasis by activating the Cofilin-F-actin pathway. Cancer Res. 2010; 70(22): 9118-9128.

34. Ding L, Zhang Z, Xu Y, Zhang Y. Comparative study of Her-2, p53, Ki-67 expression and clinicopathological characteristics of breast cancer in a cohort of northern China female patients. Bioengineered. 2017; 8(4): 383-392.

35. Tan PY, Chang CW, Chng KR, Wansa KD, Sung WK, Cheung E. Integration of regulatory networks by NKX3-1 promotes androgendependent prostate cancer survival. Mol Cell Biol. 2012; 32(2): 399-414.

36. Decker J, Jain G, Kießling $T$, Sander $P$, Rid M, Barth TTF, Möller P, Cronauer MV, Marienfeld RB. Loss of the Tumor Suppressor NKX3.1 in Prostate Cancer Cells is Induced by Prostatitis Related Mitogens. J Clin Exp Oncol. 2016; 5: 3.

37. den Hollander J, Rimpi S, Doherty JR, Rudelius M, Buck A, Hoellein A, Kremer M, Graf N, Scheerer M, Hall MA, Goga A, von Bubnoff N, Duyster J, Peschel C, Cleveland JL, Nilsson JA, Keller U. Aurora kinases A and B are up-regulated by Myc and are essential for maintenance of the malignant state. Blood. 2010; 116(9): 1498-1505.

38. Hendrickson WK, Flavin R, Kasperzyk JL, Fiorentino M, Fang F, Lis R, Fiore C, Penney KL, Ma J, Kantoff PW, Stampfer MJ, Loda M, Mucci LA, Giovannucci E. Vitamin D receptor protein expression in tumor tissue and prostate 
cancer progression. J Clin Oncol. 2011; 29(17): 2378-2385.

39. Montgomery RB, Mostaghel EA, Vessella R, Hess DL, Kalhorn TF, Higano CS, True LD, Nelson PS. Maintenance of intratumoral androgens in metastatic prostate cancer: a mechanism for castration-resistant tumor growth. Cancer Res. 2008; 68(11): 4447-4454.

40. Kmetová Sivoňová M, Jurečeková J, Tatarková Z, Kaplán P, Lichardusová L, Hatok J. The role of CYP17A1 in prostate cancer development: structure, function, mechanism of action, genetic variations and its inhibition. Gen Physiol Biophys. 2017; 36(5): 487-499.
41. Heidegger I, Kern J, Ofer P, Klocker H, Massoner P. Oncogenic functions of IGF1R and INSR in prostate cancer include enhanced tumor growth, cell migration and angiogenesis. Oncotarget. 2014; 5(9): 2723-2735.

42. Weinstein D, Sarfstein R, Laron Z, Werner H. Insulin receptor compensates for IGF1R inhibition and directly induces mitogenic activity in prostate cancer cells. Endocr Connect. 2014; 3(1): 24-35.

43. McFarlane RJ, Wakeman JA. Meiosis-like functions in oncogenesis: a new view of cancer. Cancer Res. 2017; 77(21): 5712-5716. 